\title{
Histamine release from gut mast cells from patients with inflammatory bowel diseases
}

\author{
H Nolte, N Spjeldnaes, A Kruse, B Windelborg
}

\begin{abstract}
Inflammatory mediators from intestinal mast cells may serve as initiators of acute and delayed inflammation. Mast cell histamine release was measured in 19 patients with inflammatory bowel diseases using gut mast cells from enzymatically dispersed endoscopic forceps biopsy specimens of macroscopically inflamed and normal tissue. Mast cells and corresponding basophils were challenged with anti-IgE, anti-IgG, subclass anti-IgG and formyl-methionyl-leucyl-phenylalanine (FMLP) and results were compared with those from nine patient control subjects.
\end{abstract}

The mast cell count in patients with ulcerative colitis was increased compared with that in control subjects and patients with Crohn's disease, and the mast cell count obtained from inflamed tissue was greater than that of normal tissue. The study also shows the heterogeneity of the responsiveness of the histamine releasing cells to various secretagogues. Thus, mast cells released $0.4(0 \cdot 0-2 \cdot 0)$ (median (range)) ng histamine per sample at anti-IgE challenge, and basophils were also anti-IgE responsive. In contrast, mast cells did not respond to FMLP but the corresponding basophils did. Gut mast cells released 0.3 $(0 \cdot 0-1 \cdot 0)$ (median (range)) ng histamine per sample at anti-IgG 4 challenge; however, the corresponding basophils did not respond to anti-IgG ${ }_{4}$. In addition, the anti-IgG 4 mediated histamine release was primarily confined to patients with inflammatory bowel disease.

This study substantiates previous histopathological findings that mast cells may play a functional role in the inflammatory process of inflammatory bowel diseases and provides evidence for a possible role of subclass $\mathrm{IgG}_{4}$ as a reaginic antibody.

Mast cells may play a part in the inflammatory reaction associated with inflammatory bowel diseases. ${ }^{1-4}$ The potential pathophysiological role of mast cell histamine release is based on histopathological findings and measurements of tissue histamine, however, ${ }^{35-7}$ and functional mast cell studies have not been performed because of the difficulty in handling and assaying histamine in biological specimens. Recently, a sensitive and specific glass fibre assay of histamine ${ }^{8}$ has been developed to measure histamine fluorometrically from dispersed intestinal mast cells using small biopsy specimens. ${ }^{9}$ We used this method to study the histamine release response to various secretagogues from mast cells obtained from patients with inflammatory bowel diseases.

\section{Materials and methods}

PATIENTS AND PATIENT CONTROLS

Twenty eight subjects were included in the study after informed consent had been given. Eighteen patients with active inflammatory bowel disease were classified into Crohn's disease and ulcerative colitis according to clinical features, endoscopic findings, and histopathological examination. The nine control subjects were patients being examined for adenoma. In the patient control subjects, 10 endoscopic forceps biopsy specimens (Olympus biopsy forceps FB-13 u) of mean (SD) $10.3(0.2) \mathrm{mg}$ were obtained. In patients with inflammatory bowel disease five biopsy specimens of $10 \cdot 8(0.6) \mathrm{mg}$ were obtained from macroscopically normal and inflamed tissue. Some $5 \mathrm{ml}$ EDTAanticoagulated blood were collected by venepuncture in all subjects.

\section{REAGENTS}

Anti-IgE (461.620 U/ml) was obtained from Behringwerke (West Germany). Monoclonal antibody against $\mathrm{IgG}_{4}$ subclass was obtained from Unipath (Bedford, United Kingdom) and polyclonal rabbit antihuman IgG from Dakopatts (Copenhagen, Denmark). N-formylmethionyl-leucyl-phenylalanine (FMLP) was obtained from Sigma. Collagenase $(0 \cdot 15 \mathrm{U} / \mathrm{mg})$ from Boehringer-Mannheim. The histamine releasing agents were diluted in Pipes-AMC buffer. ${ }^{8}$ Glass microfibre prepared microtitre plates were provided by Lundbeck Diagnostics (Copenhagen, Denmark).

\section{MAST CELL DISPERSION}

The biopsy specimens were dispersed mechanically and enzymatically, as described elsewhere. ${ }^{9}$ Briefly, the specimens were immediately transferred to $5 \mathrm{ml}$ Pipes-AMC at $4^{\circ} \mathrm{C}$. Within one hour they were dispersed during incubation for 90 minutes at $37^{\circ} \mathrm{C}$ in a buffered salt solution containing collagenase $(0.015 \mathrm{U} / \mathrm{ml})$, penicillin $(75 \mathrm{U} / \mathrm{ml})$, streptomycin $(75 \mu \mathrm{g} / \mathrm{ml})$, and supplemented with $20 \%$ fetal calf serum. After incubation, the cells were washed three times and pooled in $1.0 \mathrm{ml}$ of Pipes-AMC. The mast cell number was assessed by light microscopy using Kimura's metachromatic stain, and mast cell numbers were determined in a Bürker-Türk haematocytometer. ${ }^{9}$ The mast cells looked granulated and structurally intact. Cell viability, as assessed by trypan blue exclusion, was greater than $95 \%$ in dispersed cells. The mast cells were resuspended to a final concentration of $7 \times 10^{4}$ mast cells $/ \mathrm{ml}$ (SD $1 \cdot 8 \times 10^{3} / \mathrm{ml}$ ). Then mast 
TABLE I Patient characteristics

\begin{tabular}{lll}
\hline Patient group & $M: F$ & Age $(y r)$ median (range) \\
\hline Patient control subjects $(\mathrm{n}=9)$ & $5: 4$ & $47(35-69)$ \\
Ulcerative colitis $(\mathrm{n}=9)$ & $5: 4$ & $31(17-53)$ \\
Crohn's disease $(\mathrm{n}=10)$ & $7: 3$ & $36(26-41)$ \\
\hline
\end{tabular}

TABLE II Mast cell counts per mg tissue (median (range))

\begin{tabular}{llc}
\hline Patient group & Normal tissue & Inflamed tissue \\
\hline Patient control subjects & $1250(0-1750)$ & - \\
Ulcerative colitis & $1500(0-2250)$ & $2000(1500-3500)$ \\
Crohn's disease & $1250(0-2500)$ & $1750(1500-2250)$ \\
\hline
\end{tabular}

TABLE III Number of subjects releasing $>0 \cdot 1 \mathrm{ng}$ histamine/ sample in response to the various secretatogues

\begin{tabular}{llll}
\hline & \multicolumn{3}{c}{ Mast cells } \\
\cline { 2 - 4 } & & $\begin{array}{l}\text { Tissue: } \\
\text { non- } \\
\text { inflamed }\end{array}$ & $\begin{array}{l}\text { Tissue: } \\
\text { inflamed }\end{array}$ \\
\hline Patient group & Basophils & & \\
\hline Patient control subjects $(\mathrm{n}=9)$ & & & - \\
Anti-IgE & 8 & 7 & - \\
Anti-IgG & 0 & 1 & - \\
FMLP & 6 & 0 & 7 \\
Ulcerative colitis $(n=9)$ & 6 & 5 & 5 \\
Anti-IgE & 0 & 2 & 0 \\
Anti-IgG & 2 & 0 & 3 \\
FMLP & 10 & 3 & 5 \\
Crohn's disease $(n=10)$ & 0 & 2 & 0 \\
Anti-IgE & 4 & 0 & \\
Anti-IgG & & & \\
FMLP & & &
\end{tabular}

FMLP $=$ formyl-methionyl-leucyl-phenylalanine.

cells from inflamed and normal tissue were incubated separately.

\section{BASOPHIL AND MAST CELL HISTAMINE \\ RELEASE}

Histamine release from mast cells and basophils was measured as previously described. ${ }^{910}$ Briefly, $50 \mu \mathrm{l}$ 'washed' EDTA-anticoagulated blood was placed in a glassfibre prepared microtitre plate. In the wells of another microtitre plate, $30 \mu \mathrm{l}$ dispersed mast cell samples were placed.

The samples were incubated for 60 minutes at $37^{\circ} \mathrm{C}$ at the following final dilutions: FMLP at $1 \times 10^{-8} \mathrm{M}, 10^{-5} \mathrm{M}$, and $10^{-3} \mathrm{M}$, anti-IgE at 1 , 100 , and $1000 \mathrm{U} / \mathrm{ml}$, and polyclonal anti-IgG and monoclonal anti-IgG 4 at $10^{-5}, 10^{-4}, 10^{-3}$, and $10^{-2}$ $\mathrm{v} / \mathrm{v}$. After incubation histamine was measured by the fluorometric O-pthaldialdehyde method. ${ }^{8}$ The histamine release was calculated on the basis of a histamine standard curve included in all experiments. The histamine released from unstimulated samples (spontaneous release) was subtracted from the histamine released from stimulated samples to give the net stimulated histamine release. ${ }^{9} \mathrm{~A}$ histamine release of

TABLE IV Mast cell histamine release ( $\mathrm{ng} /$ sample)(median (range))

\begin{tabular}{|c|c|c|c|c|c|c|}
\hline \multirow[b]{2}{*}{ Secretagogue tissue } & \multicolumn{2}{|l|}{ Anti-IgE } & \multicolumn{2}{|l|}{ Anti-IgG } & \multicolumn{2}{|l|}{$F M L P$} \\
\hline & Normal & Inflamed & Normal & Inflamed & Normal & Inflamed \\
\hline Patient control subjects & $0 \cdot 3(0-1 \cdot 4)$ & - & $0(0-0.4)$ & - & 0 & - \\
\hline Ulcerative colitis & $0 \cdot 4(0-2 \cdot 0)$ & $0.4(0-1 \cdot 8)$ & $0(0-0.3)$ & $0.2(0-0.6)$ & 0 & 0 \\
\hline Crohn's disease & $0.3(0-0.8)$ & $0.6(0-1.5)$ & $0(0-0.6)$ & $0.2(0-1.0)$ & 0 & 0 \\
\hline
\end{tabular}

FMLP $=$ formyl-methionyl-leucyl-phenylalanine.
$>0 \cdot 1 \mathrm{ng}$ histamine per sample was considered significant. 9

\section{STATISTICS}

The Mann-Whitney test was used when comparing the mast cell counts. The Wilcoxon signed rank test was used when comparing the values for each patient. The tests of significance, median, range, mean, and standard deviation reported are calculated from the mean (SD) for triplicate determinations.

\section{Results}

PATIENTS AND TISSUE SAMPLES

Mucosal specimens from nine patients with ulcerative colitis (median age 31 years; range 17-53 years) and 10 patients with Crohn's disease (median age 36 years; range $26-41$ years) were obtained by endoscopic biopsy (Table I). Two patients with ulcerative colitis were treated with 5-aminosalicylic acid and one patient with Crohn's disease was given oral steroids. These patients, however, did not release histamine from either mast cells or basophils.

AVERAGE MAST CELL YIELDS

No significant difference in dispersed mast cell count compared with normal controls was found in normal tissue (macroscopically and histologically verified) from patients with Crohn's disease (Table II). In contrast, an increased mast cell count was found in normal tissue from patients with ulcerative colitis compared with patient control subjects $(p<0.05)$. In addition, the mast cell count obtained from inflamed tissue was greater than that from normal tissue $(p<0.01)$.

\section{MAST CELL HISTAMINE RELEASE}

Anti-IgE. Fifteen of 28 subjects released histamine to anti-IgE challenge and mast cells released histamine from both inflamed and normal tissue (Table III). Histamine release tended to be increased in inflamed tissue from patients with Crohn's disease, but this was not significant ( $p>0.05$, Table IV).

Subclass IgG. Polyclonal anti-IgG did not elicit histamine release in any subjects (results not shown). In contrast, monoclonal anti-IgG induced significant $(>0 \cdot 1 \mathrm{ng}$ histamine/sample) histamine release in 10 patients with inflammatory bowel disease and one patient control subject (Table III). The mast cell histamine release from inflamed tissue compared with normal tissue was significantly increased (Table IV, $\mathrm{p}<0.05)$.

FMLP. Incubation of mast cells with FMLP failed to induce a significant increase in histamine release above spontaneous values.

\section{COMPARISON BETWEEN MAST CELLS FROM} NON-INFLAMED AND INFLAMED TISSUE

Table III shows that more patients responded with mast cell histamine release to anti-IgE and anti-IgG 4 challenge from inflamed tissue than 
TABLE V Basophil histamine release (ng/sample) (mean (range))

\begin{tabular}{llll}
\hline Patient groups & $\begin{array}{l}\text { Anti-IgE } \\
\text { basophil }\end{array}$ & $\begin{array}{l}\text { Anti-IgG } \\
\text { basophil }\end{array}$ & $\begin{array}{l}\text { FLMP } \\
\text { basophil }\end{array}$ \\
\hline Patient control subjects & $1 \cdot 4(0-2 \cdot 0)$ & 0 & $0 \cdot 2(0-0 \cdot 6)$ \\
Ulcerative colitis & $0 \cdot 7(0-1 \cdot 8)$ & 0 & $0 \cdot 3(0-0 \cdot 4)$ \\
Crohn's disease & $0 \cdot 8(0 \cdot 2-3 \cdot 2)$ & 0 & $0 \cdot 2(0-0 \cdot 5)$ \\
\hline
\end{tabular}

from normal tissue. Hence, 10 patients with inflammatory bowel disease released histamine from inflamed tissue mast cells at anti-IgG challenge but the corresponding normal tissue mast cells showed histamine release in four patients only.

With regard to anti-IgE, there was a discrepancy in responsiveness between normal tissue mast cells and inflamed tissue mast cells in two patients only. One patient who did not respond to anti-IgE challenge showed mast cell histamine release at anti-IgG 4 challenge solely.

\section{BASOPHIL HISTAMINE RELEASE}

Anti-IgE. Twenty four of 28 subjects showed basophil histamine release to anti-IgE challenge. The anti-IgE mediated basophil histamine release compared with mast cell histamine release was increased in patient control subjects $(\mathrm{p}<0.05)$. No such difference was found between mast cells and basophils in patients with inflammatory bowel disease (Tables IV and V).

Anti-IgG. None of the subjects released histamine from basophils at challenge with subclass anti-IgG 4 or polyclonal IgG.

$F M L P$. FMLP caused histamine release in basophils. Compared with anti-IgE mediated basophil histamine release, the number of subjects responding to FMLP was smaller and the amount of histamine (ng/sample) was also decreased $(p<0.05)$.

\section{COMPARISON BETWEEN CORRESPONDING}

BASOPHILS AND MAST CELLS

The response to mast cell anti-IgE challenge in patients with Crohn's disease was noticeably reduced compared with results obtained from their corresponding basophils. Although mast cells did not respond to FMLP, their corresponding basophils released histamine on FMLP challenge. In contrast, anti-IgG ${ }_{4}$ induced mast cell histamine release and no basophil histamine release.

\section{Discussion}

This study shows that gut mast cells may release histamine in response to various secretagogues and may thus play a functional role in the inflammatory process of inflammatory bowel disease. To assess immunologically stimulated histamine release, unsensitised dispersed mast cells were challenged with anti-IgE. The results indicate the presence of functional IgE in the intestinal mast cells allowing immunological cell activation.

It is known that human basophils and mast cells may also bind to IgG antibodies other than IgE. Some authors suggest that allergen specific
$\mathrm{IgG}_{4}$ may react as allergen neutralising antibodies. There is, however, controversy over whether $\mathrm{IgG}_{4}$ antibodies adhere to relevant membrane receptors on mast cells. It is surprising that subclass anti- $\operatorname{IgG}_{4}$ was able to trigger histamine release from gut mast cells. The results suggest, however, the presence of functional Fc receptors and the presence of not only IgE but also IgG $_{4}$ in gut mast cells. The anti-IgG mediated histamine release, however, was predominantly confined to patients with inflammatory bowel disease. This suggests that mast cells in these patients possess higher amounts of $\mathrm{IgG}_{4}$ than IgE compared with normal subjects. A noticeable local IgG response, with an increase in the proportion of IgG immunocytes, has previously been found in inflammatory bowel disease. ${ }^{7}$ Attention has been focused on a local IgG response as a 'second line' of mucosal defence, however, and a local pathogenetic effect of subclass $\mathrm{IgG}_{4}$ antibody has not been considered. Thus, the histamine releasing effect of anti-IgG ${ }_{4}$ may reflect a pathogenetic role of $\mathrm{IgG}_{4}$ antibodies in inflammatory bowel disease. To elucidate this finding further, passive sensitisation with subclass $\mathrm{IgG}_{4}$ antibodies should be performed." The corresponding basophils were not responsive to anti- $\mathrm{IgG}_{4}$, confirming previous findings. ${ }^{12}$

FMLP is a potent histamine secretagogue in human basophils and these results show that in mast cell dispersates no significant histamine release was induced. This indicates that dispersates were not contaminated with basophils. Furthermore, our results show the heterogeneity between human basophils and mast cells with regard to the difference in response to various inducers of histamine release as previously found. ${ }^{13-17}$

In conclusion, the microtitre assay of histamine is a convenient method of studying the functional aspects of intestinal mast cells in patients and the method may also prove useful in investigating the effect of various drugs on dispersed gut mast cells from patients with inflammatory bowel disease as well as elucidating part of the immunological mechanisms in these diseases.

We thank Mrs E M Raaby for her skilful technical assistance and the nurses in the endoscopic laboratory for their help in collecting the tissue specimens.

This study was supported by grants from the Lundbeck Foundation and Lundbeck Diagnostics A/S, Denmark. Funding was also provided by the Aarhus University Research Grant no 1987-7131/01-5.

1 Lemanske RF, Metcalfe DD. Gastrointestinal mast cells in health and disease. 7 Pediatr 1983; 103: 177-84.

2 Barrett KE, Metcalfe DD. The mucosal mast cell and its role in gastrointestinal allergic diseases. Clin Rev Allergy 1984; 2 : in gastroin.

3 Lloyd G, Green FHY, Fox H, Mani V, Turnberg LA. Mast cells and immunoglobulin $\mathrm{E}$ in inflammatory bowel disease. Gut 1975; 16: 861-6.

4 Dvorak AM, Monahan RA, Osage JE, Dickersin RG. Mas cell degranualtion in Crohn's disease. Lancet 1979; i: 498.

5 Dvorak AM, Monahan RA, Osage JE, Dickersin RG. Crohn's disease: Immunological inflammatory response. Alterations of mast cells, basophils, eosinophils, and the microvasculature. Hum Pathol 1980; 11: 606-19.

6 O'Donoghue DP, Kumar P. Rectal IgE cells in inflammatory bowel disease. Gut 1979; 20 : 149-53.

7 Kett K, Rognum TO, Brandtzaeg P. Mucosal subclass distribution of immunoglobulin G-producing cells is differdistribution of in ent in ulcerative colitis and Croh.
Gastroenterology 1987; 93: 919-24.

8 Skov PS, Norn S, Weeke B. A new method for detecting histamine release. Agents Actions 1984; 14:414-6. 
9 Nolte H, Skov PS, Kruse A, Schiøtz PO. Histamine release from dispersed human intestinal mast cells. A method using
biopsies from children and adults. Allergy $1989 ; 44: 543-53$.

10 Nolte H, Schiøtz PO, Stahl Skov P. A new glass-microfibre based histamine analysis for allergy testing in children. Results compared with conventional leukocyte histamin release assay, skin prick test, bronchial provocation test and RAST. Allergy 1987; 42: 366-73.

11 Nolte H, Kruse A, Skov PS, Schiøtz PO. Passive sensitization of human intestinal mast cells. Agents Actions 1989; 27: 93-6.

12 Poulsen LK, Stahl Skov P, Mosbech H, Weeke B. Role of IgG4 in histamine release from human basophil leukocytes. Int Arch Allergy Appl Immunol 1988; 86: 383-90.

13 Fox CC, Kagey-Sobotka A, Schleimer RP, Peters SP, MacGlashan DW, Lichtenstein LM. Mediator-release from human basophils and mast cells from lung and intestinal human basophils and mast cells from lung and intestinal
mucosa. Int Arch Allergy Appl Immunol 1985; 77: 130-6.
14 Fox CC, Wolf EJ, Kagey-Sobotka A, Lichtenstein LM. Comparison of human lung and intestinal mast cells.

15 Nolte H, Schiøtz PO, Kruse A, Stahl Skov P. Comparison of intestinal mast cell and basophil histamine release in children with food allergic reactions. Allergy 1989; 44: $554-65$.

16 Lowman MA, Rees PH, Benyon RC, Church MK. Human mast cell heterogeneity: Histamine release from mast cell dispersed from skin, lung, adenoids, tonsils, and colon in response to IgE-dependent and nonimmunologic stimuli. f Allergy Clin Immunol 1988; 81: 590-7.

17 Tharp MD, Kagey-Sobotka A, Fox CC, Marone G, Lichtenstein LM, Sullivan TJ. Functional heterogeneity of human mast cells from different anatomic sites: In vitro responses to morphine sulfate. $\mathcal{F}$ Allergy Clin Immunol 1987; 79: $646-53$. 